\title{
BECOMING-AFTER: The Lives and Politics of Quinine's Remains
}

\section{TOWNSEND MIDDLETON \\ University of North Carolina at Chapel Hill}

(iD) https:/ / orcid.org/0000-0002-1439-5678

As dawn breaks over Darjeeling's cinchona plantations, a young man ambles across the lawn of a dilapidated colonial bungalow — a wooden mallet in one hand, a smartphone in the other. Bundled up against the Himalayan brisk, he saunters to a gong hanging at the terrace's edge, waiting to ring in a new day. Below, villages tucked into stands of cinchona poke their heads up from the morning mist. He stares into his phone, an incandescent beacon amid the morning gray. The pixels flash 6:00 a.m. and he strikes the gong in one confident swing, allowing it several seconds to reverberate before striking again. This is the wake-up bell. The ritual will repeat at 6:30 a.m., with the call to morning muster. And again at 7:00 a.m., with the commencement of the day's ganti (counting). The routine has stirred many a generation on these cinchona plantations. By 7:00 a.m., laborers are wending their way down footpaths from their homes to the maidan (field), where the day's ganti and muster are under way. They arrive quietly in dribs and drabstwo here, three there - many still rubbing the sleep from their eyes. On arrival, they duck into a concrete hut to check in with their gangmen, who dutifully record their presence in over-sized ledgers.

With their name in the books, most fail to notice the new vinyl banner hanging on the hut's side. Those who do stare perplexedly at the message: "Mero Bāgān, 
Mero Garwa” (My Plantation, My Pride), it reads, extolling the virtues of the land and work at hand. It is something of a head-scratcher: the plantations have been in decline for decades. The quinine extracted from cinchona's bark is no longer the primary treatment for malaria that it once was. With the pharmaceutical market for their product almost fully eroded, these cinchona plantations no longer produce the life-saving medicine for which they were founded. The industry's demise is everywhere apparent: in the cinchona trees growing unkempt on the surrounding hillsides; in the once-pioneering, now-shuttered Government Quinine Factory; and in the work culture of laborers playing out the string of an industry whose time has seemingly come and gone. So it is understandable that most pay the banner little mind as they make their way to their respective corners of the field to await the day's orders. At 7:15 a.m., the head gangman begins barking orders. With their assignment called, the laborers file silently back up the footpaths to their homes, where they will eat breakfast with their families, put on their work clothes, and steel themselves for another day of working the remains of a once-vital industry.

$$
* * *
$$

Today, quinine is most commonly known as the bitter ingredient in tonic water. Historically, however, this alkaloid served a more profound purpose. For centuries, quinine was the only known remedy for malaria. Extracted from the bark of cinchona, the miraculous "fever tree" native to highland South America, quinine became integral to the colonial project throughout much of the world. ${ }^{1}$ European empires invested heavily in the antimalarial, clandestinely appropriating cinchona varietals from indigenous South America; establishing transcontinental networks of plantations, labs, and factories; and orchestrating a global quinine trade in which private capital and cartels ruled the day. As the alkaloid made its way into the bodies of troops fighting world wars, peasants plowing fields throughout the tropics, and colonial officials sipping gin and tonics across the world, quinine coursed through the bloodstream of empire. Vital to colonial health and power, it was, in Hegelian terms, a "world-historical” substance (Hegel 1991): a material that profoundly altered the course of history.

Quinine proved indispensable to British rule in India (Mukherjee 1998; Veale 2010; Deb Roy 2017). Beginning in the 1860s, the British Indian government established massive cinchona plantations in the Darjeeling region in a desperate attempt to secure medicinal autonomy for the empire. Thousands of workers, mostly Nepali-speaking Gorkhas from the surrounding hills, came to this medical 


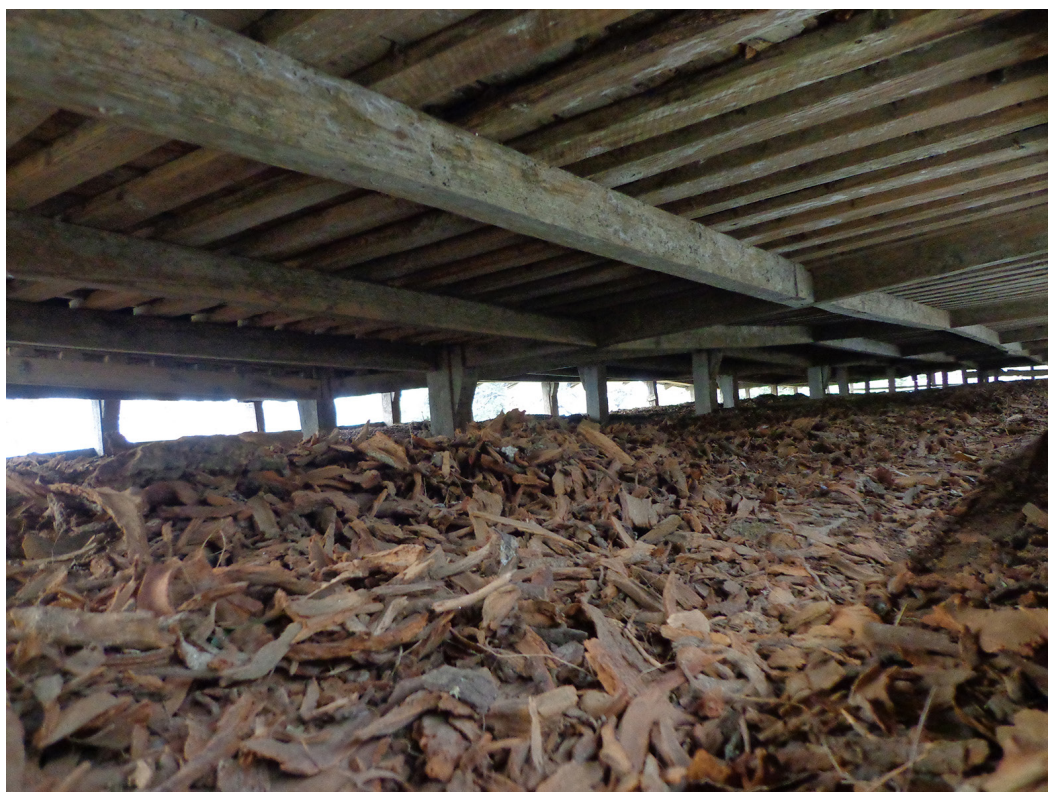

Figure 1. Cinchona bark, Darjeeling, 2017. Photo by Townsend Middleton.

frontier to cultivate the plant and strip the tree of its precious bark. Factories were erected to transform the bark into life-saving quinine doses, which were then distributed across the subcontinent and beyond through elaborate dispensary systems. The quinine made at Darjeeling saved countless lives during its colonial career.

But for the communities who made it, quinine has left grave uncertainty in its wake. The World War II-era advent of synthetic compounds like chloroquine and the insecticide DDT prompted paradigmatic shifts in the global fight against malaria. With today's pharmaceutical market dominated by synthetic antimalarials, artemisinin-based combination therapies (ACTs), and stronger, cheaper quinines from Africa, demand for Indian quinine has vanished. Yet, despite not having produced a dose in decades, government cinchona plantations first established by the British in the nineteenth century still exist in the Darjeeling hills — albeit in a dilapidated state. The Indian government has labeled the industry "sick" and has targeted it for privatization, but local communities, led by strident unions, have successfully resisted. So far. What is to become of the industry - and the roughly fifty thousand people who inhabit its remains - is unclear. Shuttered quinine factories and unkempt cinchona trees may conjure images of ruination, but these remains are anything but dead. Darjeeling's cinchona plantations have instead become the site of urgent efforts - and a periodically charged politics - to redefine land and life for the twenty-first century. For those who call the plantations 


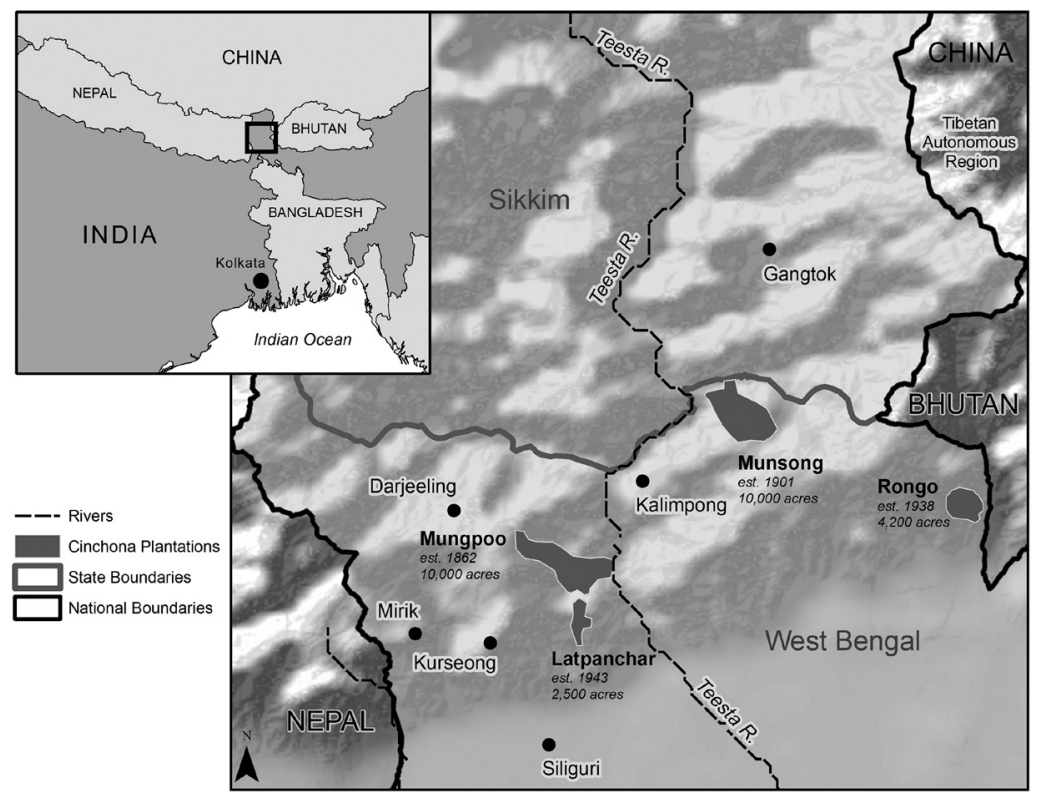

Figure 2. The colonial cinchona frontier in the Darjeeling hills. Map prepared by UNC-Libraries.

home, quinine's remains constitute the grounds on which any viable future must be forged (Middleton 2019). More immediately, they are the grounds on which the present must be lived and defended.

Beginning with Sidney W. Mintz's (1986) pioneering work on sugar and continuing through anthropology's multispecies turn, we have learned more and more about how particular plants and chemicals shaped human history. The aftermath of such world-historical substances demand extended exploration. This essay situates itself amid quinine's living remains. It asks not only how history, empire, and life itself were made with things like quinine but also, crucially: What happens after these game-changing substances have run their course?

Historically, the existence of India's cinchona plantations seems unremarkable. Malaria killed and cost millions throughout the colonial period. That the British Raj brought cinchona from South America to Darjeeling and made the plant, land, and humans work to imperial ends is no revelation. That's what empire does. And no complex was more comprehensive in this mutual disciplining of human and nonhuman life than the plantation - a point underscored in recent conversations of the Plantationocene led by Donna J. Haraway and Anna L. Tsing (2019; see also Besky 2020). What is remarkable, anthropologically, is that India's cinchona plantations still exist. The plantations have been hemorrhaging government funds for decades. Much of their infrastructure has deteriorated beyond use. Factories 
and drying sheds are crumbling. Machinery is corroded. Soils are exhausted. After years of neglect, once-manicured stands of cinchona saplings have happily outgrown their sixteen-year harvest cycle and become unruly forests of thick trunks and gnarled roots - their aging bark diminished of the alkaloid for which they were planted. Raw bark production has slowed to a trickle of its former levels. Quinine manufacturing has ceased entirely. Yet somehow these cinchona plantations remain. This is no historical accident, but rather owes to the political work and persistence of those who call the plantations home.

In her writing on Mumbai's seemingly antiquated mill-workers, Maura Finkelstein (2019) warns against the analytic dangers of reading such spaces as anachronistic or allochronistic. "The mill is not a relic from the past," she notes; "while [it] may invoke a sense of pastness, this orientation toward ruin forecloses our ability to engage it as a lively and vital space of modernity. This is a crisis of temporality" (Finkelstein 2019, 13). For Darjeeling's cinchona workers fighting to maintain their presence in the present, coevelness (Fabian 1983) is precisely what is at stake. Temporality is critically important to their politics.

Developing an analytic of becoming-after, I turn to quinine's remains to explore what people do when the historic products that centered their lives lose their place and value in the world. How does life come back together (or not) once the market collapses, once the factory closes and the fields go fallow? How, who, and what do communities become after the world-historical substances of one era give way to those of the next? Such questions of becoming-after refract across the postcolonial and postindustrial world, from the coal countries and rust belts of the global North to the archaic plantations and exhausted landscapes of the global South. These spaces may appear worn out, anachronistic, and left behind by the putative march of history, but in them stir some of the most critical questions of our times: none more perplexing than how to make something new-or at least viable_—with the remains of the old.

Engaging the politics of becoming-after, I draw on ethnographic fieldwork on Darjeeling's cinchona plantations (2015-2019), as well as on archives and oral histories with plantation workers, managers, union leaders, and others to explore life and politics after quinine. Generations after this world-historical substance ceased to be the first-line treatment for malaria, it continues to generate an array of politics, temporalities, and im/possibilities that fundamentally structure life in its wake. Amid this aftermath, the future appears marked more by constraint than unbridled possibility. India's cinchona plantations remain, in many ways, bound 
by their colonial past, yet hope and a discernable politics animate their present. The sections that follow probe these dialectics of constraint and possibility that shape the prospects of becoming-after quinine. After a brief elaboration of the analytic of becoming-after, I turn to communities' struggles to defend the plantations against privatization to explore the temporality of local politics after quinine. Next, I examine residents' attempts to escape the clutches of the plantations' undying colonial past. In conclusion, I consider the ethical ambiguities of the workand value — of maintaining the present to buy time for figuring out a more just version of what comes next.

\section{ON BECOMING-AFTER}

The analytic of becoming-after that I propose here brings together two lines of anthropological inquiry: the first concerns humanity's becoming with animals, plants, and chemicals (honed by multispecies ethnography [Kirksey and Helmreich 2010; Kirksey 2014], planthropology [Myers 2017], and chemo-ethnography [Shapiro 2015; Shapiro and Kirksey 2017], respectively); the second concerns postcolonial and postindustrial ruination (see, for instance, Benjamin 1998; Stoler 2008, 2013, 2016; Fortun 2014; Walley 2014; Tsing 2015; Finkelstein 2016, 2019; Murphy 2017). Haraway, in her Companion Species Manifesto (Haraway 2003) and subsequent When Species Meet (Haraway 2008), has called for us to examine how humans "become with" (Haraway's formulation) our nonhuman counterparts. Additional discussions of becoming, often drawing on Gilles Deleuze and Félix Guattari's (1987, 257-72) emphasis on the openness of becoming, have gone on to highlight the plastic, durative nature of these co-becomings: we are always in a process of becoming with our human and nonhuman others (Dave 2014; Wright n.d.). As João Biehl and Peter Locke (2017, 6) elaborate in their volume, Unfinished, "Becoming is characterized by the indeterminacies that keep history open, and it allows us to see what happens in the meantimes of human struggle and daily life" (see also Fischer 2018). Although not necessarily historical in their orientation, these analytics of becoming and becoming with can help illuminate how history, empire, and life itself were made with cinchona and quinine (cf. Deb Roy 2017).

My analysis builds on these more-than-human attentions by extending the temporal frame to question what happens after: after the historic rise, after the fall, after the proverbial medicine has run its course. Becoming-after similarly attunes us to the materiality of things, but in another time and space: not so much in the makings of more-than-human worlds, but in their unmakings and potential remakings. To probe the after is to examine all that remains and transpires in a 
world-historical substance's wake. Similar to the post in Stuart Hall's postcolonialism, the after signals neither a clean nor epochal break with the past but rather a contemporary wrestling with its remains: material, ideational, human, and otherwise. "It is what it is," as Hall might have it, "because something else has happened before, but it is also something new" (see Drew 1999, 230). For those who dwell in quinine's wake, the after forms a time-space of both impossibility and possibility. For the inheritors of these aftermaths, becoming-after is an ongoing project: something to be worked on and worked at. ${ }^{3}$ And it is a horizon: something to work or orient toward, using the immediate stuff at hand. ${ }^{4}$

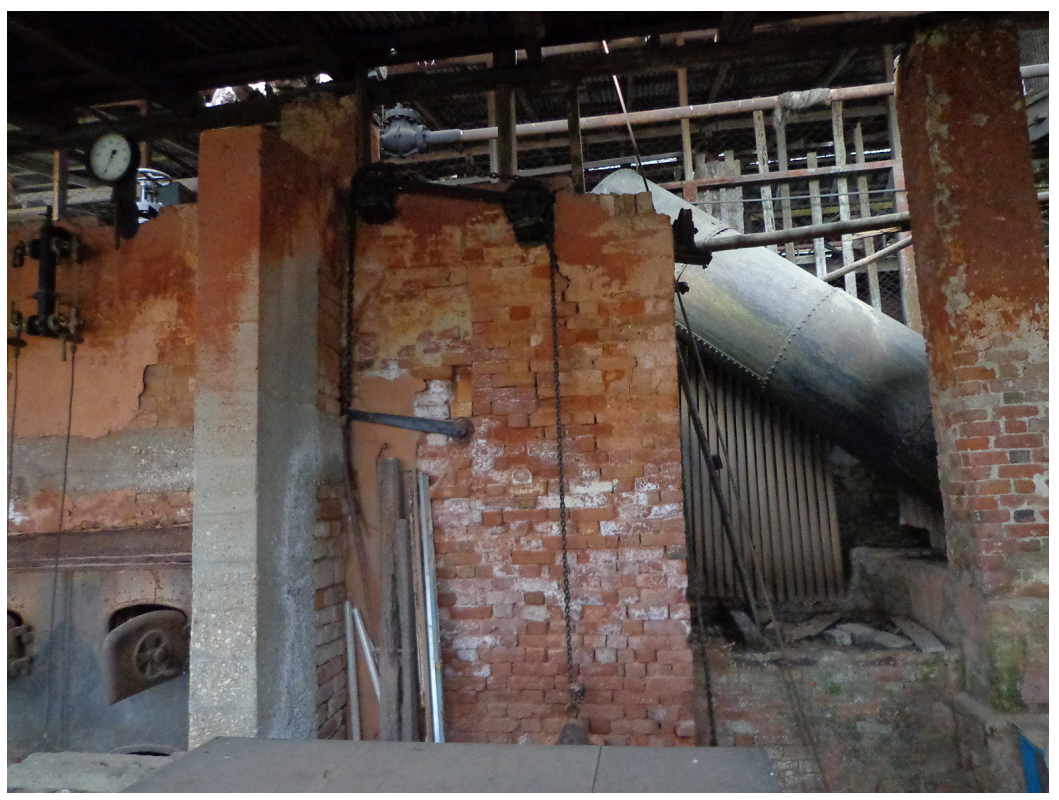

Figure 3. Remains of the Government Quinine Factory, Darjeeling, 2017. Photo by Townsend Middleton.

The becomings that interest me with becoming-after unfold on the tired grounds and crumbling factories of the postindustrial, postcolonial world. Materiality matters in these contexts (Tsing 2015; Finkelstein 2019), though not always in the ways it once did. Rusting factories are not easily rebuilt. Exhausted soils do not rejuvenate overnight. Aging infrastructure-and laboring bodiescannot simply be made young again. On Darjeeling's cinchona plantations, these material intransigencies (Collier 2011) combine with a plantation institution that has stubbornly outlived its product to produce a distinctive breed of postcolonial, postindustrial precarity. For those who dwell amid these aftermaths, the horizons 
of becoming-after are less open to possibility than they are constrained by prior conditions.

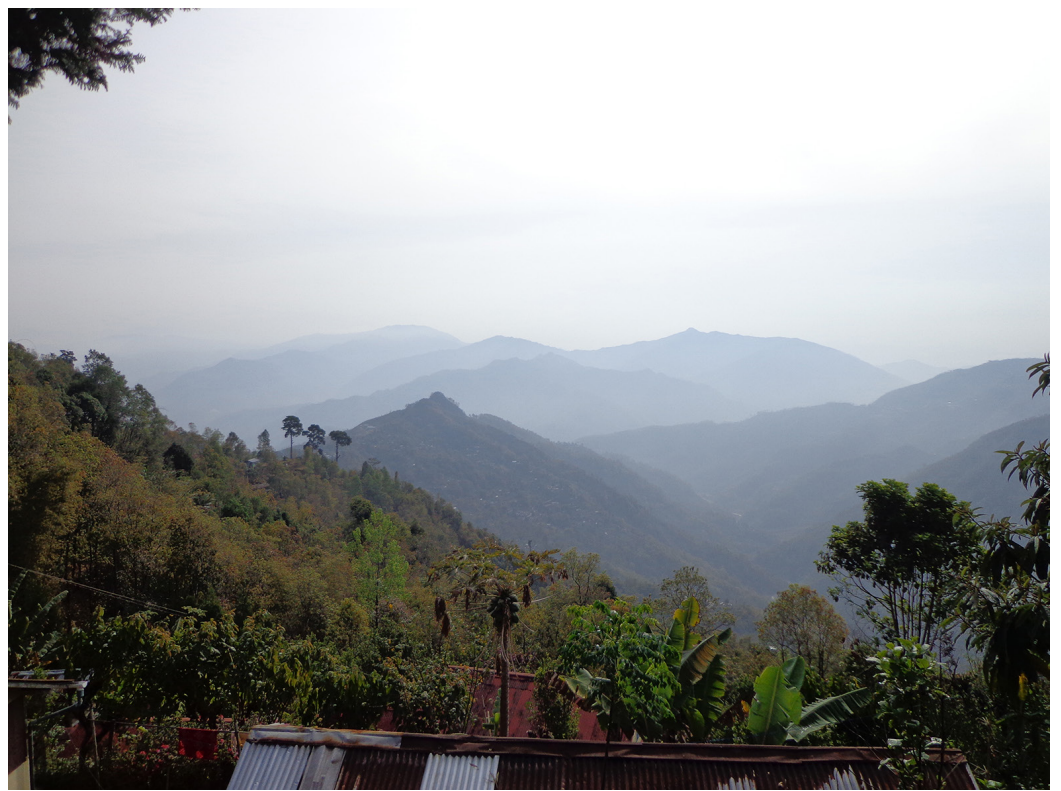

Figure 4. Cinchona plantations at Mungpoo, Darjeeling, 2017. Photo by Townsend Middleton.

In sketching the Plantationocene as an epochal alternative to the Anthropocene, Haraway and Tsing (2019) frame the plantation as the modal complex of capitalism's more-than-human ruination. Yet because the Plantationocene presumes a ruined and blasted landscape — the detritus of capital's world-making — it risks occluding a more vital reality: the politics of those who continue to make (meaningful) life within actual plantations. Ask cinchona workers, and they will be the first to explain how the plantations' aging infrastructure, diminishing biochemical energies, and stubborn institutional logics continue to constrain them. They will be the first to tell you of the uncertainty that haunts them. The precarity is palpable. But so are affective ties to these plantations. So are the efforts for a better future. These endeavors of becoming-after beckon ethnographic engagement beyond the Plantationocene's reckonings of more-than-human ruination. For residents, the plantations are not (in) ruins. Neither are they blasted. They are home-places that, despite their constraints, afford vital forms of stability and belonging amid the other forms of extraction loosed upon the world. Cinchona workers have accordingly chosen to defend the plantations and the lifeways they afford. 
They are not alone. Sarah Besky's (2013, 2017, 2020) research on the nearby private tea estates of Darjeeling and the Dooars similarly illustrates the solidarities between workers, plants, and land that define plantations as living spaces. Andrew C. Willford's (2014) study of Tamils defending their place in Malaysia's defunct rubber plantations shows how plantations can be anchors of identity and belonging in a rapidly changing world (see also Li 2017). ${ }^{5}$ These defenses of the contemporary plantation can be hard to locate in the theoretical landscape of the Plantationocene. Yet it is worth remembering that workers live on plantations. They become-with the land, plants, machines, and all the rest - and not all, or only, as slaves or bonded labor. For the Gorkhas who settled on India's colonial cinchona plantations as wage-laborers generations ago, the plantations' more-than-human ecology became the grounds not only of livelihood but also of community and belonging. These latter have proven to have greater staying power than quinine itself.

Despite far-from-ideal conditions, these communities have chosen to defend the plantations as their home. As I detail below, living and working on plantations producing little in the way of products or prospects entails a daily dose of paradox and sacrifice. But for the moment, dealing with these sacrifices today feels necessary to finding a dignified life after quinine, tomorrow. Lacking clear answers as to what comes next, theirs is not so much a politics of the future as of the present - a politics of the meantime. ${ }^{6}$

\section{PERSISTING CAPITAL}

It is seldom a good sign when foreigners in suits show up in places like Darjeeling's cinchona plantations. Worse still, when they come back. In 1991, finance minister and future prime minister Manmohan Singh announced the "liberalization" of India's economy. The embrace of free market capitalism opened the door to the privatization of many of India's public utilities and government-run industries. It did not take long before investors came calling on the supposedly sick quinine industry. By 1992-1993, representatives of Hindustan Lever, a subsidiary of the transnational Unilever, and their international consultants from PricewaterhouseCoopers were prowling the cinchona plantations, surveying the resources on offer. These included 26,000 acres of topographically diverse land, the labor potential of more than 50,000 residents, and industrial infrastructure, not all of which was beyond repair.

The ensuing events - here reconstructed through oral histories and ethnographic engagement with many of the key players - have become legendary on the plantations. In workers', trade union activists', and community leaders' tell- 
ings, local hackles went up as soon as the suits were spotted surveying the plantations. Suspicions were confirmed when Hindustan Lever subsequently unveiled its proposal to convert the entirety of the cinchona plantations over to tea. The public-private partnership (PPP) proposed significant labor retrenchment, land expropriations, and infrastructural overhauls. The proposal met immediate backlash. Foreseeing the end of lifeways generations in the making, the cinchona trade unions launched strikes and gherao-ed (publicly harassed) officials. This was a force that PricewaterhouseCoopers had missed in their scrupulous reports. Hindustan Lever quickly recognized the oversight and walked back the plan. They returned with another proposal to retain some cinchona, while converting much of the plantations to tea.

In 1996, the West Bengal government convened a meeting of stakeholders in the nearby city of Siliguri to discuss the plan with hopes of moving it forward. The trade unions had other ideas. The meeting, which began in staid fashion with representatives of Hindustan Lever, PricewaterhouseCoopers, and government agencies gathered around a boardroom table, soon erupted into chaos. Shouting at the officials, trade union leader Renulina Subba, the "Iron Lady" of cinchona, led union members in staging a dramatic walkout. The cinchona unions subsequently called region-wide strikes (bandhs) to oppose privatization.

Politicians, meanwhile, worked behind the scenes to salvage the deal. In 2017, I met with the trade union secretary L. M. Sharma to revisit those tumultuous days when life with cinchona teetered on the brink. The revered labor leader, now getting on in age but still with fire in his eyes, recalled, "The local MLA [member of the legislative assembly] took us to Writer's Building [the state capital in Kolkata] and arranged for a meeting with the minister of commerce. . . . We had quite a heated discussion with him. He insisted that cinchona is a losing concern." Sharma and his cadres countered by insisting that the plantations were rich with untapped potential. They explained how cinchona cultivation could be combined with timber and other initiatives to create a portfolio that would allow the plantations to carry on without undue burden to the state. Their pleas seemed to strike a chord with the Left Front government official, Sharma noted. West Bengal's then-ruling Communist Party of India-Marxist (CPI-M) maintained an active union (CITU) presence on the plantations. Since the 1970s, the Left Front's ideological affinity for labor had served as a buffer of sorts for the troubled cinchona plantations. But the bottom line was the bottom line: the government industry was hemorrhaging state funds. Hoping to stop the bleeding, the Left Front government continued to court the handover to Hindustan Lever. 
Field managers, nearly all of them Gorkhas with deep connections to the plantations, found themselves at the fulcrum of the controversies, balancing the government orders of the Cinchona Directorate and the concerns of laborers and their volatile unions. "The government was trying to give as much of it [the plantation system] away as possible," a manager I came to know well during fieldwork remembered; "they were just trying to get rid of it." Laborers, meanwhile, were growing increasingly leery of the men in suits. With rumors swirling that a secret deal was imminent, the situation came to a head in 1997, when Hindustan Lever and PricewaterhouseCoopers representatives convened at the plantation headquarters in Mungpoo. The trade unions summoned their members to crash the meeting. Some made their way inside and began hurling furniture through the windows before seizing the proposal and ceremoniously burning it. Spooked by the escalations, Hindustan Lever, at the advice of the government, gave up the ghost and walked away. This time they did not come back.

The turning away of Hindustan Lever marked an important victory in the fight against privatization, but it was not long before other suits came calling - in the late 1990s, they arrived from Dabur India Ltd, a manufacturer of ayurvedic medicine. Cinchona did not bring them; it was the land. Specifically, they eyed the fertile hills for the cultivation of taxus buccata, a natural cancer treatment. But because their proposal largely neglected to address either cinchona or local livelihoods, the unions again mounted a successful opposition and drove Dabur away.

The government found itself in a bind. By its own ideology, West Bengal's Left Front could not ignore the well-being and political will of its fifty thousand cinchona residents. Then again, what was to be done with an industry without a market? In 2002, West Bengal hired the international consultant firm McKinsey \& Company to help answer that question. Hoping to head off resistance, the local district magistrate (DM) summoned trade union and political leaders to his office to explain the government's logics. One of the invited leaders, the late R. B. Chhetri, a preeminent local intellectual, ${ }^{7}$ remembered the DM framing the situation in terms of darkness and light. "The cinchona plantations are now going through a tunnel of darkness," Chhetri recalled the DM proclaiming. "For survival, you see a light there. And that light is privatization. Else you will remain inside the tunnel."

Dark metaphors aside, McKinsey consultants were enlightened of a different view when they began their assessment. A mob of plantation union members confronted the team at Mungpoo, demanding that the consultants reveal their true intentions. The confrontation turned violent and someone snatched files from a consultant's hand. As one witness I interviewed recounted, "When the mob saw 
the McKinsey files, they burned them. That's when they [McKinsey] ran away." For the third time in a decade the unions had managed to chase away the threat of privatization.

That numerous private investors have eyed the putatively sick industry following liberalization hardly seems surprising. Labor's opposition-especially given the industry's dire condition-warrants a closer look, however. How are we to understand the persistence and vitriol with which the unions drove away private capital? Are there lessons in the ashes of the proposals snatched from prospective investors and burned?

Cinchona laborers' resistance to privatization has centered on safeguarding what are known as the "facilities" guaranteed by their work on the government plantations — none more important than land. Unlike on Darjeeling's tea estates, where laborers receive paltry plots for kitchen gardens (Besky 2013, 2017; Sen 2017), cinchona laborers have long enjoyed access to fields - some more than an acre in size - to accompany their government-provided housing. The discrepancy stems from how the British quinine project mapped onto the steep terrain of $\mathrm{Hi}$ malayan Darjeeling.

The colonial makings of Darjeeling's cinchona plantations were unusual in several ways. Notably, this plantation system was not geared toward profit (at least not directly), but instead toward the production of cheap medicine for the general population (after, of course, colonial officials). The British government framed its quinine industry as an imperial and a humanitarian endeavor. In the words of the secretary of state to India in 1875 , the aim was "not to be a commercial object, but one having reference solely to the supply of a cheap febrifuge to the people of India." ${ }^{8}$ While history would eventually lay bare the imperial priorities of the project, what is important for understanding the contemporary politics of becoming-after is that the government-run cinchona plantations were never themselves intended to generate profit. This fundamentally impacted how the land was and was not capitalized.

Then there was cinchona's peculiar botany. Each varietal requires specific combinations of elevation, soil, sunlight, temperature, and moisture to survive. The finicky tree from the Andes gave colonial botanists fits when they first attempted to grow it in India. Darjeeling, where elevations quickly range from four hundred to seven thousand feet above sea level, eventually proved one of the few sites where cinchona thrived. ${ }^{9}$ Yet because this precipitous landscape can vary so rapidly from one acre to the next, finicky cinchona could never achieve the crop coverage of tea. At most, cinchona has covered roughly one-third of the planta- 
tions' acreage. This left significant land for other purposes, like labor. As it looked to secure a stable workforce for its critically important quinine industry, the colonial government was thus able to promise wages, housing, and ample land - often doling out acres at a time to workers and their families. ${ }^{10}$ Passed down through the generations, these homesteads have allowed workers and their families to maintain a relatively comfortable peasant existence alongside their wage labor. Plantation residents continue to use these lands to grow fresh vegetables and raise livestock mostly for domestic use. These facilities and their attendant forms of belonging have been — and remain_- defining features of life with cinchona.

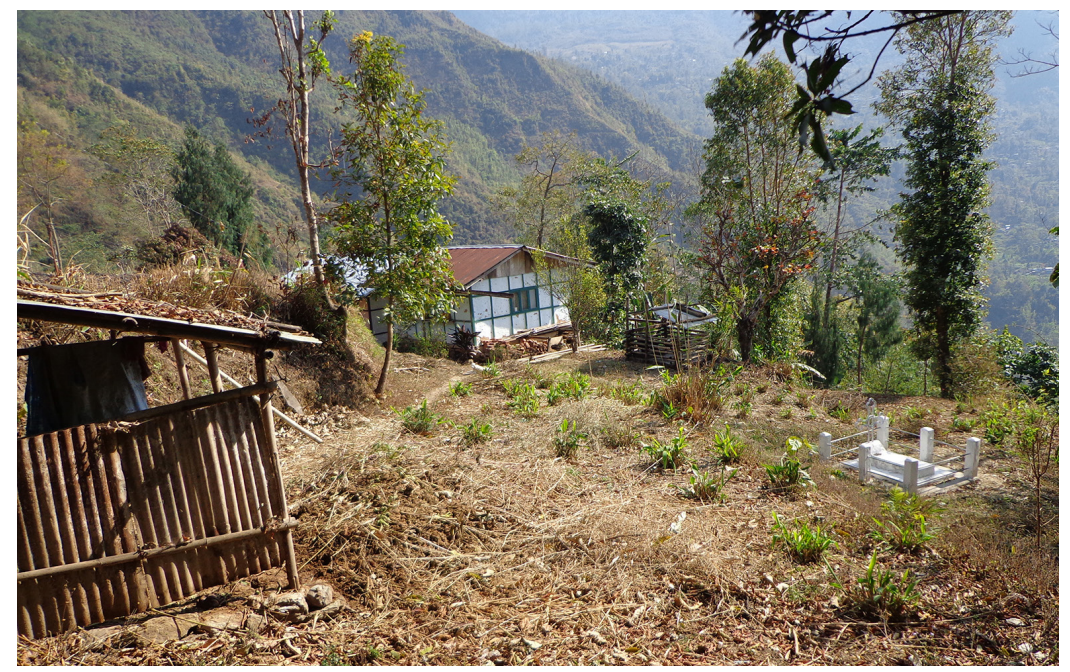

Figure 5. Worker's homestead, Kalimpong, 2017. Photo by Townsend Middleton.

Privatization directly threatened these lifeways. Cinchona residents are quick to point out the plantations' distinctive character when justifying their resistance. "Cinchona has its own ways of functioning. It is not a private enterprise," a manager who grew up on the plantations, a "son of the soil," told me over tea in 2019. "The people who are here have lived [here] for generations, and if Hindustan Lever tells a worker that it is not able to take him in, then what will happen to the family that is dependent on the worker? The land that has been allotted to the family will now belong to Hindustan Lever. So that is a huge thing."

These entanglements of labor, land, family, history, and life itself ran through many of the testimonies I gathered during fieldwork. When I interviewed the late R. B. Chhetri in his plantation home in 2017, the renowned leader and intellectual elaborated on these more-than-human attachments that define life in the cinchona 
plantations and make these spaces worth defending. "The land is precious," he told me, looking back on his years opposing privatization. "We have emotions, sentiments, belongingness, attachment, culture, and society attached to our homes. I would never give up this home of mine. . . . They [Hindustan Lever] understood they had stirred a hornet's nest. And that's when they left."

Crucially, it is not only these sentiments of home that have made the cinchona plantations a hornet's nest. In the context of the region's recurrent Gorkhaland Movement, the plantations have become battlegrounds for ethnic autonomy, territory, and belonging in India. Since the colonial period, the region's Nepali-speaking Gorkha majority have been exploited, racially discriminated against, and marginalized as outsiders in India, despite their legal citizenship and demonstrated loyalties to India. Starting in 1986, the Gorkhaland National Liberation Front (GNLF) waged a violent three-year struggle for a separate state of Gorkhaland in India. The aim was to free the region and its people from the neocolonial clutches of West Bengal, their archenemy, and thereby establish the Gorkhas' rightful place in India. Because the cinchona plantations were (and remain) the property of the government of West Bengal, they became a front line of the subnationalist struggle. Clashes between unions loyal to Gorkhaland (like those of the GNLF and Gorkha League) and those associated with West Bengal's ruling CPI-M (like CITU) made the plantations a violent arena. The movement also turned on the Cinchona Directorate itself, destroying property, kidnapping officers, and reappropriating government resources to myriad ends. Ultimately, though, the agitations failed to deliver a separate state.

The situation repeated in 2008, when the Gorkha Janmukti Morcha (GJM), the newest liberation front, launched a second Gorkhaland Movement. The GJM made it an expressed goal to pry the plantations from the grip of West Bengal. The 2008-2011 agitation also failed to deliver Gorkhaland. It did, however, achieve the transfer of the Cinchona Directorate to the newly minted Gorkhaland Territorial Administration in 2012, a conciliatory government of limited autonomy, still within West Bengal. The small victory proved misleading when it emerged that it was only the directorate (i.e., the administrative apparatus) of the cinchona plantations that had been transferred, not the land and resources. Those remained the property of West Bengal. Cinchona plantation residents considered this an affront perpetuating a long history of colonial domination - first by the British, then by Bengalis. As one local leader exclaimed to me during a particularly animated conversation in 2017, “These rulers from Kolkata have very colonial designs. Colonial designs!” 
He spoke these words less than three months after a devastating third Gorkhaland agitation had crippled life on the plantations and across the region for 104 days during the monsoon months of 2017. The destruction, food shortages, and casualties again were to little avail. The Darjeeling hills, at present, remain part of West Bengal. The cinchona plantations, home to more than fifty thousand Gorkhas, remain the property of the government of West Bengal.

The Gorkhaland agitations put the resistance to privatization into ethnopolitical context. The same sentiments of "belongingness, attachment, culture, and society" that fueled the fight with Hindustan Lever motivate the movement for Gorkhaland. Both the plantations and Gorkhaland are home-one nested inside the other. Through three traumatic agitations, the politics of Gorkhaland have reanimated the cinchona plantations as a distinctively ethnic space: a markedly different kind of claim on quinine's remains than those of the postcolonial government or private investors. Imbuing these spaces with tremendous affect and periodic violence, the Gorkhaland Movement has made the cinchona plantations all the more difficult and dangerous places for outsiders to do business: a hornet's nest.

And yet, despite the volatilities, capital keeps coming back. Recent years have seen numerous piecemeal attempts to develop the plantations. Proposals for eco-tourism resorts, ashrams, and universities have largely gone nowhere, owing to local resistance and the legal-political complexities of privatizing government lands. Yet the plantations have ceded ground to other governmental uses: ninety-one acres were allocated to the National Hydro-Electric Power Corporation (NHPC) for the damming of the Teesta River in 2003, and smaller parcels went to an Industrial Training Institute (ITI) in 2016 (five acres) and a government tourist complex in 2017 (six acres). Although small in comparison to the wholesale overhauls pitched by Hindustan Lever, for those defending the plantations such land grabs portend a future of further loss (Middleton 2019, 208).

Most residents believe it is only a matter of time before additional private investors come calling. Per the logics of privatization, after all, India's cinchona plantations have lost their raison d'être. With cinchona growing wild, its bark rotting, and the quinine factory beyond repair, the plantations themselves would seem to be decomposing into ruins, unused spaces, and "waste lands." Such tropes should sound an alarm for students of British imperialism in India, where the waste lands designation functioned as a legal mechanism to expropriate massive tracts of ostensibly uninhabited land. ${ }^{11}$ Unlike the native cultivators (ryots) of these lands, who were conveniently ignored, displaced, and written out of imperial histories of primitive accumulation, the people of cinchona today are refusing to become 
subalterns. Their struggles concern not so much being written out of history as maintaining their presence in the present. Theirs is a politics of remaining - a politics of persistence.

Quinine's remains, they attest, are not dead. Struggles for the future of these lands and lives hinge precisely on the fact that there is (or could be) life in these remains - human, material, and otherwise. For communities fighting to remain amid the remains, to admit to the deadening terms of ruins and ruination could prove devastating. Many plantation residents and leaders I have come to know through fieldwork cling to the possibility that India's quinine industry will be rejuvenated. Experts familiar with the science and economics of quinine (e.g., botanists, chemists, and others) doubt that possibility, however. India's cinchona plantations can no longer compete with the Congo's, they told me. Any talk of quinine's rebirth is a "political drama," as one plantation chemist called it, meant only to keep hope - and the status quo - alive. Are the hopes of a future in cinchona, then, an instance of what Lauren Berlant calls "cruel optimism," that "condition of maintaining an attachment to a problematic object in advance of its loss" (Berlant 2007, 33; emphasis original)? Yes and no. More interesting, I suggest, is the temporality of their optimism - that maintaining. When unions dig in against the threat of privatization and insist that the cinchona plantations can be revitalized, they strategically pry open the present in the name of the life in the remains - human and otherwise. Doing so, they parry the advance of unwanted futures and buy themselves time to find a better alternative.

Today, the directorate and residents are piloting new crops on the plantations. Experimental cultivations of orchids, kiwi, mushrooms, coffee, and ginger build on prior diversification efforts that have included rubber, citrus, and medicinal ipecac and dioscorea. Not one of these crops has individually shown a clear path out of the present impasse, but unions and many plantation officers believe a viable combination can be found. This will, however, take time, work, and investment.

The semiotics of development proposals snatched and burned in this setting are hard to miss but easy to misinterpret. Destroying the bids of Hindustan Lever, PricewaterhouseCoopers, and McKinsey \& Company does not represent an obstinate clinging to the status quo. Neither does it enact a cruel optimism extending the agony of an inevitable loss to come. Cinchona trade unions and the people they represent do not reject change. Their contention concerns what kind of change the future will entail. When the cinchona workers look across to their neighbors on Darjeeling's private tea estates, they see precisely the kind of morethan-human ruination one would expect in the Plantationocene. Besky's (2013) 
work on Darjeeling's tea plantations, as well as her more recent discussions (Besky 2020) of starvation on the Dooars' tea plantations, offer chilling portrayals of these deprivations of land and life. That cinchona workers have vehemently rejected tea as an option therefore comes as little surprise; this is a community built around a very different colonial plant and project. Cinchona plantation residents do not lack a sense of futurity. They may lack definitive answers to what the future may hold, but they are centrally concerned with the question of the future. Heading off catastrophe and staying open to alternatives here entails its own form of what Adriana Petryna calls "horizoning work," wherein (in this case) unions and workers orient their current action to possible futures and thereby "secure enough time to act while avoiding a norm of horizon deprivation" (Petryna 2018, 588; emphasis original). Most residents recognize that things cannot go on as they are and that this may mean parting with the objects - cinchona, quinine - that have defined their livelihoods for generations. But until and unless an acceptable future comes into view, they have chosen to persist and, where necessary, fight.

The meantime may not be ideal, but it is better than succumbing to the depredations of privatization. With the plantations deteriorating around them and capital on the prowl, cinchona's trade unions and communities know that time is not necessarily on their side. But time is also precisely what they need, before all else, to find a way forward. And so they continue to maintain and defend their presence. Their politics are clear: there is life - and lives - in quinine's remains that must be accounted for.

\section{A PRESENT TETHERED TO THE PAST}

To see life in the remains is not to ignore the tremendous constraints they impose. While cinchona's finicky nature may have opened space for the unique lifeways discussed earlier, the fever tree does much to dictate the prospects of becoming-after. Cinchona has grown ever more obdurate. Where saplings once lined the hills in orderly 4'x4' plots, these stands have now become entangled forests of mature, knotty trees. One of the most hated jobs on the plantations involves uprooting these long-neglected trees. Yet that is what is required to clear space for something new — be it rubber, ginger, coffee, or new cinchona stands, all of which are being piloted.

The mature trees that remain are, moreover, diminished of alkaloid content. After generations of relentless overproduction and then decades of neglect, the plantations' exhausted soils and unkempt trees are yielding barks with less than 2.5 percent quinine. This renders them unable to compete with the East African 


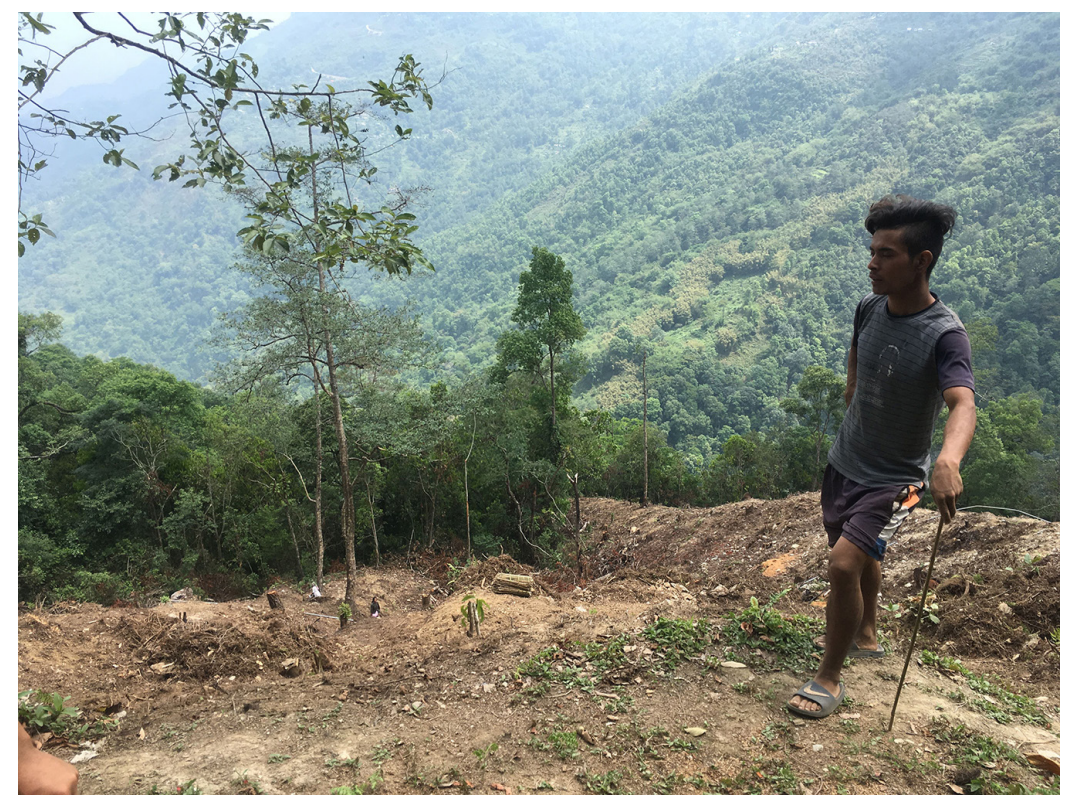

Figure 6. Laborers clear a hillside for new cinchona, Kalimpong, 2019. Photo by Townsend Middleton.

barks that yield alkaloid contents as high as 9 percent (WBLA 2004) and that dominate the global market for beverage and medicinal quinine.

The chemical manufacturing side of the industry has suffered a parallel decline. Lacking the research and development to keep afloat in a rapidly changing pharmaceutical market, the Government Quinine Factory's extraction techniques grew dated from the 1950s onward. The factory's aging machinery, by the 1970s, could no longer handle the volume of bark grown on the surrounding hills. Budgets ran short and manufacturing inputs stopped showing up on time. The factory sputtered through the 1980 s and 1990 s_-sometimes running at capacity, sometimes lying in wait for the required materials to produce its product. In 2000, when the factory produced its last dose of quinine, it did not so much formally close as simply stop working once and for all. Since then, sacks of bark have sat deteriorating on the factory's floor - a telling disarticulation of the field-to-factory nexus.

Looking to breathe some life into this scene (or at least garner some votes), Darjeeling's then political leader, Bimal Gurung, goaded the Cinchona Directorate into revitalizing the factory for a test run in 2014. With some tinkering and a fresh coat of paint, the sleeping giant roared back to life, proving that it could still make quinine. However, the entire facility now fell below the Good Manufacturing 


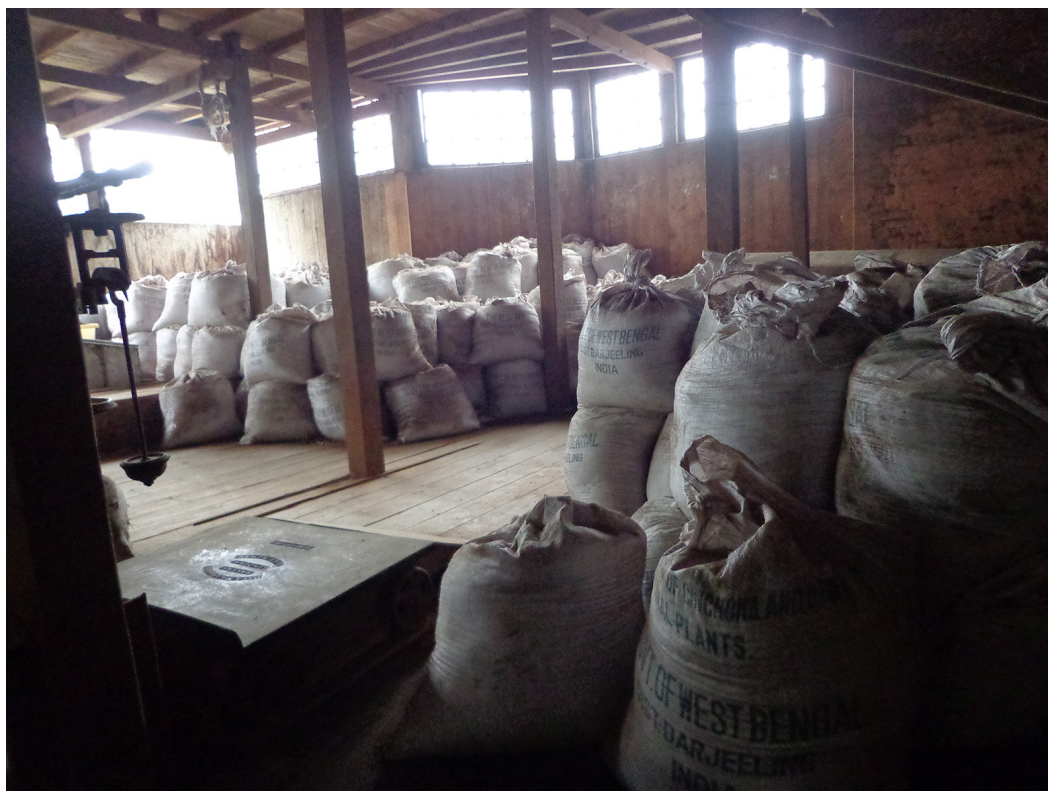

Figure 7. Cinchona bark rots in the factory at Mungpoo, Darjeeling, 2017. Photo by Townsend Middleton.

Practice (GMP) standards required to sell on the national and global market. Updating the factory into compliance would require massive capital investments - a nonstarter for an industry long in the red. And so, after the briefest of awakenings, the Government Quinine Factory again sits dormant and deteriorating.

Surveying these remains, one must remember that decolonization shifted the biopolitical calculus on which the enterprise was founded. The British intended Darjeeling's quinine industry to be a biomedical backstop for empire. Its top priority was the health of colonial officials, but as a cheap, government-made, and widely distributed drug it also served India's general population - a public good for the public good. The 1940s marked the advent of not only India's independence (1947) but also of synthetic antimalarials and DDT. Both became game-changers in the war on malaria. With the paradigm shifting, India's independent government relinquished the colonial designs of its quinine industry, leaving this vestige of a bygone biopolitics little chance of surviving in a contemporary medical landscape dominated by big pharma. Materially, technically, and ideationally, Indian quinine, in the postcolonial era, became an industry "out of time," in more senses than one (cf. Finkelstein 2019).

Nothing, however, tethers the present to the past quite like the plantation system itself — particularly its institutional disciplining of land and labor. As dis- 
cussed earlier, the rule on the cinchona plantations - known as badli käm - has always been that one member of each family must remain a full-time employee in order to receive the government-provided facilities of homes, land, and the like. The ability to live on the government plantations therefore hinges on the passing down of employment from one generation to the next. The system has allowed about five to six thousand official cinchona employees to support a population of now roughly fifty thousand residents. Never mind that the plantations are no longer producing quinine: to remain, one must have one's name (or a family member's name) recorded in the books. Daily.

On a rainy summer afternoon in 2019, my research assistant, Vikash (himself a "son of the cinchona soil") and I convened a group of plantation workers to discuss cinchona's present realities and future possibilities. There, on a hillock with experimental crops all around and cinchona growing unkempt in the distance, the workers - all men between the ages of twenty-one and fifty-talked us through their frustrations and hopes. Their testimonies, spoken over lashing rains and hot tea, told of a present troublingly bound by quinine's historic past. Anit framed the experience as one of compulsion and sacrifice:

You asked right at the beginning what the situation of cinchona is right now and what can happen in future. The situation at present shows a dark future. The young generation has a future that is gloomy, the reason being the system of cinchona is already collapsing. ... But we have a compulsion. We have to sacrifice a family member, a son, to work on the cinchona. This is our compulsion. . . . We have to save our homestead, our land. And it is for this very reason, one son has to stay back in the plantation to safeguard the shelter that the family has. We are sacrificing our educated sons for the safety of our homes. We are turning the educated young man into a laborer. He is going to be a laborer forever. So we are mindfully, purposefully sacrificing the future of our son, even if he is educated, for the sake of this system.

Anit, it turns out, spoke from experience. He was one of those educated youth. A sharp intellect had helped him earn a law degree. But, as the only family member who could fulfill the employment requirement when his father passed, the plantation reeled him back in. He took the position to save his family homestead. He even arranged for substitute workers to take his place in the field so that he could continue to pursue his law career in the nearby city of Darjeeling. When cinchona administrators caught wind of this, however, they issued a letter to the Darjeeling 
court explaining that, as a scheduled government cinchona laborer, he was legally bound to another kind of work, not in the courts, but in the plantations. Such was the compulsion and sacrifice of Anit - a trained lawyer, but in the archaic logic of the plantation, forever a laborer.

Anit's project of building a life beyond quinine has accordingly found itself bound by the unrelenting institutions of the plantation. His quandaries echo across the plantations, particularly among the youth. With the industry offering little prospects for the future, more and more have sought education and employment outside the plantations, whether in the nearby cities of Darjeeling, Kalimpong, and Siliguri or farther afield in Kolkata, Bangalore, and New Delhi. Yet many know they may be called back and compelled to sacrifice their ambitions to support their family's basic means of existence. That these plantations are no longer making the life-saving drug for which they were founded only underscores the paradox and perversity of these sacrifices.

Quinine's aftermath adds a sobering note to the anthropology of becoming, which has tended to look optimistically to becoming's open-endedness as a way to explore possibilities of other futures (Biehl and Locke 2017, 29; Wright n.d.). Insofar as the projects and politics of becoming-after quinine are vested with hope and possibility, they share in this Deleuzian embrace of the open and unknown. Their difficulties, however, warrant a deeper historical, causal explanation. ${ }^{12}$ For plantation residents, quinine's colonial past constantly drags at the present, severely limiting who and what they can be (or become). Encumbered by this temporal drag (Freeman 2010, 62), Anit and his peers embody a distinctly postindustrial form of precarity, comprising equal parts uncertainty over what the future holds and the intransigence of an industry's material and institutional remains. ${ }^{13}$ In such circumstances, the horizons of becoming-after are seldom open and free, but, more typically, tethered and troubled.

Unable to pursue his otherwise bright future in law, Anit has consequently found himself stuck in the aftermath: the reluctant inheritor of quinine's remains. What to make of these remains - and how to live with them - is thus the challenge rung in daily by the morning bell. It is both an individual and a shared project. And so Anit rubs the sleep from his eyes to begin the work at hand.

\section{AN ETHIC/S FOR THE TIME-BEING}

In a world indelibly shaped by colonial, industrial, and anthropogenic change, it would seem that even in the freest of circumstances (certainly a far cry from the postcolonial plantation), people are never fully after what came before. Rather, 
they are always making do-and to the extent possible, re-becoming — with the remains of their pasts. I have offered becoming-after as an analytic for exploring these conditions, projects, and horizons of unequally inhabited im/possibilities. Varying by context and community, becoming-after will look different in postsugar Puerto Rico (Mintz 1986) or Belize (Moran-Thomas 2019) than it will in post-quinine Darjeeling. Its work, politics, and feel will manifest differently amid the toxic "enfleshments" of North American settler industrialism (Walley 2014; Murphy 2017) versus the deafening aftermaths of gold in South Africa (Morris 2008) or Papua New Guinea (Jacka 2015). Identifying the histories of becoming-with that made these places and linking those pasts to their communities' current struggles of becoming-after is not simply a matter of history for history's sake. It is a prerequisite for ethnographically mapping the challenges and unevenness of our fundamentally affected present.

At the end of the day, figuring out what to make of life after world-historical substances have run their course is no easy matter. Like my friends on Darjeeling's cinchona plantations, I have no simple answers as to what comes definitively after quinine. That question is being worked out daily on the plantations. Because it involves such dense entanglements of human and nonhuman, past and present, and material and immaterial forces, becoming-after quinine brooks little resolution. An analytic of becoming-after is not necessarily in the business of asking "what comes next?" but rather, "what happens in the meantime?" To that end, let me offer a last look into the day-to-day realities of life in quinine's wake.

It's getting late. Around the offices of the Government Quinine Factory in Mungpoo, a dozen clerks sit at large wooden tables, watching the clock, waiting for their shift to end. In another time, these desks teemed with ledgers tabulating factory inputs, outputs, quinine extraction rates, tablets produced, and so on. In another time, clerks worked feverishly to keep pace with the pharma-industrial giant, steaming and groaning away next door. Not today. With the hulking factory padlocked, desks worn smooth by generations of paperwork now sit empty, save for a few personal items - a calendar here, a photo there. These clerks were once the factory's brains: the counters, the calculators. Yet at 2 p.m. on a Friday afternoon in 2017, the main calculations concern the clock. The clerks who have made it this long sit at empty desks, watching the minutes tick away, doing their best to complete an honest day's work. By 3:30 p.m., when I pass back through the offices after visiting the factory, the desks are all empty. The clerks have returned home. Another day in the books. 
Similar scenes are unfolding across the cinchona plantations. The most earnest of workers have lasted their full shift. Others went home hours ago. Some, having gotten their name in the books at the morning ganti, never reported at all. This is what work has become for many: the art of doing the bare minimum. This is understandable. But the lack of worker discipline (anushasan) has become a major problem for those trying to breathe new life into the industry. Although the population of rank-and-file workers has remained, thanks to the trade unions, relatively stable over the years, leadership positions have dwindled significantly. At full capacity, the plantations employed fifty-eight officer-level positions, ranging from quinologists and botanists to factory and field managers. Today, there are fewer than ten. As these experts have retired, taking with them knowledge that could prove instrumental to quinine's rebirth, the West Bengal government has not replaced their lines. Many retired managers I interviewed, all of them Gorkhas with deep attachments to the lands and livelihoods at stake, see this as the single biggest threat to the industry's future. On their more conspiratorial days, they frame it as a strategy of attrition-West Bengal's way of slowly killing a dying industry. Bereft of its leaders, the plantations lack the hierarchy to enforce the discipline that once suffused their more-than-human ecology. To a manager's trained eye, the effects are everywhere: in cinchona overgrowing its harvest cycle; in equipment rusting beyond repair; and in workers doing little more than showing up, signing in, and checking out on a daily basis. These deteriorations hamstring from the start any top-down initiative to revive the plantations.

Recall the banner at the beginning this article. The "My Plantation, My Pride" campaign formed part of a broader effort by the Cinchona Directorate to revitalize the industry. It included renewed diversification efforts through the experimental planting of ginger, coffee, kiwi, citrus, rubber, and even new cinchona. The directorate also turned attention to worker culture, heritage, and pride to pump life into the plantations. The top-down campaign began with semiannual meetings of plantation gangmen at the directorate's headquarters, where PowerPoint presentations and self-empowerment corporate-speak sought to instill purpose in the plantations' remaining leadership. The campaign likewise reached down to workers with banners and other reminders extoling the heritage and pride of the work at hand. Mero Bāgān, Mero Garwa, as it went in Nepali.

These efforts have largely fallen flat not because workers lack a sense of heritage or pride, but because the industry itself — and the world around it - has become something different. Many residents see no future in the field and factory. The afternoon after watching sleepy-eyed workers scratch their head at the ban- 
ner's perplexing message, I asked the gangman who had barked out orders on that misty morning about the challenges of leading his crew-many of whom are his friends and neighbors — into such dismal horizons. "It's tough," he told me as we bounced along in the back of a jeep on rocky plantation roads made for the British many lives ago. "People come and try to cut out of work early. They try to work as little as possible," he later explained. "Or they come to work in the fields and all they talk about is their education degrees. But I tell them: you are here to work in the fields. What are you going to do? You can't dig a hole and clear the fields with a ballpoint pen!" As conversation turned to how his workers might interpret the banner, he responded wryly: "Who knows? They might read it and feel like it's theirs. Or, [starting to chuckle] they might just rip it off and take it home and use it for something else!"

The gangman's wit captured something the banner elided: the ambivalences of inhabiting an industry's remains. Plantation workers speak nostalgically of the days when the fields flourished and the factory churned out life-saving medicine. They maintain a deep attachment to cinchona, the plant around which their lives were built, and a strong sense of belonging within the plantations. But whether the banner's message of pride and heritage "feels like theirs," as the gangman put it, is a question that throws into high relief the peculiar alienations of postindustrial labor. Thinking beyond the early Karl Marx (1978 [1844]), there is perhaps only one thing more estranging than selling one's labor to an industry that makes a product sold far from those who made it: namely, selling one's labor to an industry that makes no product at all.

And yet that is precisely what the people of cinchona must do if they wish to remain among quinine's remains. This requires a daily habitation of paradox, precarity, and, as Anit, our attorney-laborer put it, sacrifice. For communities playing out the string of an industry producing little in the way of products or prospects, these are days that cannot be gotten back. And yet, staying with the present - no matter how tethered or troubled — may be the best option for those searching for a future amid the remains of old. It may be the only option.

What then can we make of life and politics in quinine's wake? Trade unions chasing away private investors and their well-heeled consultants and mobs snatching and burning proposals of an undesirable future are easily recognizable as a politics. But what of the plantation workers for whom the morning bell tolls? What of clerks sitting dutifully at empty desks, watching the clock count down their days? Are these practices of showing up and being counted — of remaining among the remains - also a politics? These practices may not figure as perfect examples of 
resistance or "weapons of the weak" (Scott 1985), but they are compulsory - and tactical, in Michel de Certeau's (1984) sense-because they are the precondition of any subsequent politics or life in these spaces. Particularly when transformative forces loom on the horizon and no viable future is in sight, manning the present may itself make for an act of political consequence. If not a politics proper, there is an ethic here, in the Weberian (Weber 1992 [1930]) sense of a duty or calling - and an ethics, in the Kantian (Kant 1957 [1785]) sense of how one acts upon the world - for becoming-after and its anthropology: a call to the present and the ongoing work and politics thereof.

In seeking an ethnographic understanding of how, who, and what people become after the world-historical substances of one era give way to those of the next, I have come to theorize becoming-after as a condition, project, and horizon of life in a broader world of remains - colonial, industrial, and otherwise. If reckonings of ruins and ruination help us see the constraints these inheritances hand down to the present, becoming keeps us open to the possibilities that inhere in the after. We need both these attentions to appreciate the lives, politics, and im/possibilities that animate remains. At the end of the day, it is not enough simply to recognize that life exists in the remains. The real ethical and political question is: What kind of life?

From the coal countries and rust belts of the global North to the archaic plantations and exhausted landscapes of the global South, what is to be made of life after world-historical substances have run their course stands as one of the most urgent questions of our times. Though particularly acute in these contexts, the problem of becoming-after — what to make of remains and how to live with them — does not confine itself exclusively to postcolonial or postindustrial circumstances. It marks a signature challenge of the Anthropocene.

In developing an anthropology of becoming-after, I have sought to think small_ or at least ethnographically_about these big questions. Transforming quinine's remains into something viable continues to be a fraught affair for the people who live on India's cinchona plantations. Governmental regimes attempting to privatize this ailing industry, corporations looking to capitalize on its material resources, trade unions insisting on the industry's revitalization, and individuals making do with the limited resources at hand suggest a surfeit of options. Just not necessarily mutually viable or good options. Until a desirable future opens before them, cinchona's workers will heed that morning bell and continue to show up and get their names in the books. They will continue to inhabit the remains and defend the status quo, no matter how precarious. And they will continue to do their best 
to persist amid the onslaught of capital. Offering lessons for becoming-after and the anthropology thereof, theirs is a politics — and ethics — for the time-being.

\begin{abstract}
This article explores the aftermath of quinine in India. Derived from cinchona, the fever tree, quinine was once malaria's only remedy - and, as such, vital to colonial power. But it has left grave uncertainty in its wake. Today, little market exists for Indian quinine, but government cinchona plantations established by the British remain in Darjeeling. What will become of these dilapidated plantations and their 50,000 inhabitants is unclear. Crumbling quinine factories and overgrown cinchona may evoke ruination, but these remains are not dead. They have instead become the site of urgent efforts - and a periodically charged politics - to redefine land and life for the twenty-first century. This essay develops an analytics of becoming-after to ask not only, how do empires and human beings become-with world-historical substances like quinine but also, what do we make of life after they run their course? [becoming; ruins; ruination; plantations; postindustrial; postcolonial; materiality; temporality]
\end{abstract}

\title{
NOTES
}

Acknowledgments A special thanks to the communities of the cinchona plantations who made this article possible, as well as the Directorate of Cinchona and Other Medicinal Plants. I am grateful for the intellectual generosity of my reviewers and editors at Cultural Anthropology, especially Heather Paxson, who guided this piece to its final form. Eklavya Pradhan and Jason Cons offered valuable feedback on drafts, and I am grateful to all the interlocutors who commented on various presentations of these arguments along the way. My research on quinine has been supported by the Wenner-Gren Foundation, the American Institute of Indian Studies, UNC's Institute for the Arts and Humanities, the Carolina Asia Center, and other UNC sources.

1. There is a significant literature on quinine's imperial implications. For a comprehensive overview, see Rohan Deb Roy (2017).

2. As Hall writes with signature clarity, "So, postcolonial is not the end of colonisation. It is after a certain kind of colonialism, after a certain moment of high imperialism and colonial occupation - in the wake of it, in the shadow of it, inflected by it" (see Drew 1999, 230).

3. "Social projects," Elizabeth A. Povinelli (2013, 238) writes, "are activities of fixing and co-substantiating phenomena, aggregating and assembling disparate elements into a common form and purpose. The word 'project' means to convey the constant nature of such building as well as the constant tinkering with plan, draft, and scheme as the building is being made, maintained, and remade out of disparate materials."

4. The concept of horizon has grown particularly salient in decolonial studies. See, for instance, the journal Decolonial Horizons / Horizontes Decoloniales; the Pluto Press series Decolonial Options / Postcolonial Horizons; key works by Walter D. Mignolo (2011; also in conversation with Mónica González García 2006). On horizoning, see Adriana Petryna (2018).

5. Though not on plantations, Sarah Ives (2017) illustrates related entanglements of plants, belonging, and politics. 
6. These encounters between workers' lived time and other forms of temporality and power (for instance, those framing the plantations as anachronistic relics) lend themselves to the approach of power-chronography charted by Sarah Sharma's $(2014,9)$ In the Meantime.

7. Chhetri passed away in August 2020. This interview occurred in 2017.

8. West Bengal State Archive [Bengal, Agricultural, PC9, Proc29, April 1875].

9. The other main site was the Nilgiri hills.

10. In the nineteenth century, workers received anywhere from 1 to 5 acres. The allotments have steadily fallen to the current average size of 0.25 acres. Sizes of worker's fields vary by family history.

11. The notion of wastelands awaiting the civilizing hand of European capitalists dates back at least to Adam Smith (2015 [1776]). It became law in India via The Waste Lands (Claims) Act of 1863.

12. Deborah A. Thomas's (2019) historicization of contemporary politics in post-plantation Jamaica offers another example.

13. For a more hopeful reading of uncertainty and indeterminacy, see Anna Lowenhaupt Tsing (2015) and others (Tsing et al. 2017) who have explored the possibilities of life in capitalist ruins, finding patches of indeterminacy and thus possibility.

\section{REFERENCES}

Benjamin, Walter

1998 The Origin of German Tragic Drama. Introduction by George Steiner. Translated by John Osborne. London: Verso. Originally published in 1963.

Berlant, Lauren

2007 "Cruel Optimism: On Marx, Loss, and the Senses." New Formations 63, no. 8: 3351.

Besky, Sarah

2013 The Darjeeling Distinction: Labor and Justice on Fair-Trade Tea Plantations in India. Berkeley: University of California Press.

2017 "Fixity: On the Inheritance and Maintenance of Tea Plantation Houses in Darjeeling, India.” American Ethnologist 44, no. 4: 617-31. https://doi.org/10.1111/ amet.12561.

2020 Tasting Qualities: The Past and Future of Tea. Oakland: University of California Press.

Biehl, João, and Peter Locke, eds.

2017 Unfinished: The Anthropology of Becoming. Durham, N.C.: Duke University Press. Collier, Stephen J.

2011 Post-Soviet Social: Neoliberalism, Social Modernity, Biopolitics. Princeton, N.J: Princeton University Press.

Dave, Naisargi N.

2014 "Witness: Humans, Animals, and the Politics of Becoming." Cultural Anthropology 29, no. 3: 433-56. https://doi.org/10.14506/ca29.3.01.

de Certeau, Michel

1984 The Practice of Everyday Life. Translated by Steven F. Rendall. Berkeley: University of California Press.

Deb Roy, Rohan

2017 Malarial Subjects: Empire, Medicine and Nonhumans in British India, 1820-1909. Cambridge: Cambridge University Press.

Deleuze, Gilles, and Félix Guattari

1987 A Thousand Plateaus: Capitalism and Schizophrenia. Minneapolis: University of Minnesota Press. 
Drew, Julie

1999 "Cultural Composition: Stuart Hall on Ethnicity and the Discursive Turn." In Race, Rhetoric, and the Postcolonial, edited by Gary A. Olson and Lynn Worsham, 205-40. Albany: State University of New York Press.

Fabian, Johannes

1983 Time and the Other: How Anthropology Makes Its Object. New York: Columbia University Press.

Finkelstein, Maura

2016 "Landscapes of Invisibility: Anachronistic Subjects and Allochronous Spaces in Mill Land Mumbai." City and Society 27, no. 3: 250-71. https://doi.org/10.1111/ ciso. 12067.

2019 The Archive of Loss: Lively Ruination in Mill Land Mumbai. Durham, N.C.: Duke University Press.

Fischer, Michael M. J.

2018 Anthropology in the Meantime: Experimental Ethnography, Theory, and Method for the Twenty-First Century. Durham, N.C.: Duke University Press.

Fortun, Kim

2014 "From Latour to Late Industrialism." HAU: Journal of Ethnographic Theory 4, no. 1: 309-29. https://doi.org/10.14318/hau4.1.017.

Freeman, Elizabeth

2010 Time Binds: Queer Temporalities, Queer Histories. Durham, N.C.: Duke University Press.

González García, Mónica

2006 "Towards A Decolonial Horizon of Pluriversality: A Dialogue with Walter Mignolo on and around the Idea of Latin America." Lucero 17, no. 1: 38-55.

Haraway, Donna J. https://escholarship.org/uc/item/2wc8n1w4.

2003 The Companion Species Manifesto: Dogs, People, and Significant Otherness. Chicago: Prickly Paradigm Press.

2008 When Species Meet. Minneapolis: University of Minnesota Press.

Haraway, Donna J., and Anna L. Tsing

2019 Reflections on the Plantationocene: A Conversation with Donna Haraway and Anna Tsing. Moderated by Gregg Martin. Madison, Wisc.: Edge Effects.

Hegel, Georg W. F.

1991 The Philosophy of History. Translated by J. Sibree. Amherst, N.Y.: Prometheus Books. Originally published in 1822.

Ives, Sarah

2017 Steeped in Heritage: The Racial Politics of South African Rooibos Tea. Durham, N.C.: Duke University Press.

Jacka, Jerry K.

2015 Alchemy in the Rain Forest: Politics, Ecology, and Resilience in a New Guinea Mining

Kant, Immanuel Area. Durham, N.C.: Duke University Press.

1957 "Theory of Ethics." In Kant Selections, edited by Theodore Meyer Greene, 268-89.

Kirksey, Eben, ed. New York: Charles Scribner's Sons. Originally published in 1785.

2014 The Multispecies Salon. Durham, N.C.: Duke University Press.

Kirksey, S. Eben, and Stefan Helmreich

2010 "The Emergence of Multispecies Ethnography." Cultural Anthropology 25, no. 4: 545-76. https://doi.org/10.1111/j.1548-1360.2010.01069.x.

Li, Tanya Murray

2017 "The Price of Un/Freedom: Indonesia's Colonial and Contemporary Plantation Labor Regimes." Comparative Studies in Society and History 59, no. 2: 245-76. https://doi.org/10.1017/S0010417517000044. 
Marx, Karl

1978 "Economic and Philosophical Manuscripts of 1844." In The Marx-Engels Reader, edited by Robert C. Tucker, 66-101. New York: W. W. Norton. Originally published in 1844.

Middleton, Townsend

2019 "Frontier 2.0: The Recursive Lives and Death of Cinchona in Darjeeling." In Frontier Assemblages: The Emergent Politics of Resource Frontiers in Asia, edited by Jason Mignolo, Walter D. Cons and Michael Eilenberg, 195-212. London: Wiley.

2011 The Darker Side of Western Modernity: Global Futures, Decolonial Options. Durham, N.C.: Duke University Press.

Mintz, Sidney W.

1986 Sweetness and Power: The Place of Sugar in Modern History. New York: Penguin Books.

Moran-Thomas, Amy

2019 Traveling with Sugar: Chronicles of a Global Epidemic. Oakland: University of California Press.

Morris, Rosalind C.

2008 “The Miner's Ear.” Transition 98: 96-114. https://doi.org/10.2979/trs.2008..98 .96 .

Mukherjee, Abhijit

1998 "The Peruvian Bark Revisited: A Critique of British Cinchona Policy in Colonial India." Bengal Past and Present 117, nos. 1/2: 81-102.

Murphy, Michelle

2017 "Alterlife and Decolonial Chemical Relations." Cultural Anthropology 32, no. 4: 494-503. https://doi.org/10.14506/ca32.4.02.

Myers, Natasha

2017 "From the Anthropocene to the Planthroposcene: Designing Gardens for Plant/ People Involution." History and Anthropology 28, no. 3: 297-301. https://doi.org/1 $0.1080 / 02757206.2017 .1289934$.

Petryna, Adriana

2018 "Wildfires at the Edges of Science: Horizoning Work amid Runaway Change." Cultural Anthropology 33, no. 4: 570-95. https://doi.org/10.14506/ca33.4.06.

Povinelli, Elizabeth A.

2013 “The Social Projects of Late Liberalism.” Dialogues in Human Geography 3, no. 2: 236-39. https://doi.org/10.1177\%2F2043820613495784.

Scott, James C.

1985 Weapons of the Weak: Everyday Forms of Peasant Resistance. New Haven, Conn.: Yale University Press.

Sen, Debarati

2017 Everyday Sustainability: Gender Justice and Fair Trade Tea in Darjeeling. Albany, N.Y.: SUNY Press.

Shapiro, Nicholas

2015 "Attuning to the Chemosphere: Domestic Formaldehyde, Bodily Reasoning, and the Chemical Sublime." Cultural Anthropology 30, no. 3: 368-93. https://doi. org/10.14506/ca30.3.02.

Shapiro, Nicholas, and Eben Kirksey

2017 “Chemo-Ethnography: An Introduction.” Cultural Anthropology 32, no. 4: 481-93.

Sharma, Sarah https://doi.org/10.14506/ca32.4.01.

2014 In the Meantime: Temporality and Cultural Politics. Durham, N.C.: Duke University Press.

Smith, Adam

2015 The Wealth of Nations, Book IV: On Systems of Political Economy. Cambridge: Cambridge University Press. Originally published in 1776. 
Stoler, Ann Laura

2008 "Imperial Debris: Reflections on Ruin and Ruination." Cultural Anthropology 23, no. 2: 191-219. https://doi.org/10.1111/j.1548-1360.2008.00007.x.

2016 Duress: Imperial Durabilities in Our Times. Durham, N.C.: Duke University Press.

Stoler, Ann Laura, ed.

2013 Imperial Debris: On Ruins and Ruination. Durham, N.C.: Duke University Press.

Thomas, Deborah A.

2019 Political Life in the Wake of the Plantation: Sovereignty, Witnessing, Repair. Durham, N.C.: Duke University Press.

Tsing, Anna Lowenhaupt

2015 The Mushroom at the End of the World: On the Possibility of Life in Capitalist Ruins. Princeton, N.J.: Princeton University Press.

Tsing, Anna Lowenhaupt, Heather Anne Swanson, Elaine Gan, and Nils Bubandt, eds.

2017 Arts of Living on a Damaged Planet: Ghosts and Monsters of the Anthropocene. Minneapolis: University of Minnesota Press.

Veale, Lucy

2010 “An Historical Geography of the Nilgiri Cinchona Plantations, 1860-1900.” PhD diss., University of Nottingham.

Walley, Christine J.

2014 Exit Zero: Family and Class in Postindustrial Chicago. Chicago: University of Chicago Press.

WBLA (West Bengal Legislative Assembly Secretariat)

2004 "The Present State of Affairs of Cinchona Production in West Bengal: Seventh Report.” Kolkata: WBLA.

Weber, Max

1992 The Protestant Ethic and the Spirit of Capitalism. Translated by Talcott Parsons. London: Routledge. Originally published in 1930.

Willford, Andrew C.

2014 Tamils and the Haunting of Justice: History and Recognition in Malaysia's Plantations. Honolulu: University of Hawai'i Press.

Wright, Katherine

n.d. "Becomings." The Multispecies Salon: A Companion to the Book (blog). Accessed March 17, 2021. https://www.multispecies-salon.org/becomings/. 